Situs Jurnal : http://ejournal.stiepancasetia.ac.id/index.php/jieb

Jilid 6 Nomor 1 Maret 2020

Hal $128-143$

\title{
PENGARUH BUDAYA ORGANISASI DAN MOTIVASI KERJA TERHADAP KINERJA PEGAWAI DINAS KETAHANAN PANGAN, PERTANIAN DAN PERIKANAN KABUPATEN BARITO SELATAN
}

\author{
ARSULAWARENI \\ Pegawai Dinas Ketahanan Pangan, Pertanian Dan Perikanan Kabupaten \\ Barito Selatan. Jalan Buntok Ampah KM. 6,5 Buntok 73711 Telpon (0525) 21530 \\ Kabupaten Barito Selatan. awineini@yahoo.com
}

\begin{abstract}
Abstrak
Tujuan dari penelitian ini adalah untuk menganalisis pengaruh Budaya Organisasi dan Motivasi Kerja. Metode yang digunakan adalah analisis regresi linier berganda untuk mengetahui pengaruh dari Budaya Organisasi dan Motivasi Terhadap Kinerja Pegawai dengan menyebar kuesioner kepada 76 orang Pegawai Dinas Ketahanan Pangan, Pertanian Dan Perikanan Kabupaten Barito Selatan dan dilakukan selama 4 bulan.

Kesimpulan bahwa secara simultan variabel Budaya Organisasi dan Motivasi berpengaruh terhadap Keputusan Pembelian Kinerja Pegawai Dinas Ketahanan Pangan, Pertanian Dan Perikanan Kabupaten Barito Selatan, variabel Budaya Organisasi dan Motivasi secara parsial berpengaruh terhadap Keputusan Pembelian Kinerja Pegawai Dinas Ketahanan Pangan, Pertanian Dan Perikanan Kabupaten Barito Selatan, dan Variabel yang berpengaruh dominan terhadap Kinerja Pegawai Dinas
\end{abstract}

\section{Latar Belakang Masalah}

Begitu pentingnya kedudukan sumber daya manusia dalam suatu usaha sehingga menjadi penentu bagi maju mundurnya organisasi. Karena betapapun besarnya bangunan ataupun modal yang digunakan serta matangnya rencana dan strategi, semua tidak akan berarti tanpa orangorang yang melaksanakan rencana tersebut. Budaya organisasi adalah suatu sistem nilai yang diperoleh dan dikembangkan oleh organisasi dan pola kebiasaan dan falsafah dasar pendirinya, yang terbentuk menjadi aturan yang digunakan sebagai pedoman dalam berfikir dan bertindak dalam mencapai tujuan organisasi. Budaya yang tumbuh menjadi kuat mampu memacu organisasi kearah perkembangan yang lebih baik. Budaya organisasi dapat mempengaruhi profesionalisme kerja pegawai negeri sipil, karena menciptakan interaksi antar pegawai berdasarkan karakteristik budaya organisasi yang antara lain meliputi inovasi, kemantapan, kepedulian, orientasi hasil, perilaku pemimpin, orientasi tim, karakteristik tersebut terdapat dalam organisasi mereka Persepsi pegawai negeri sipil mengenai kenyataan terhadap budaya organisasinya menjadi dasar pegawai negeri sipil berperilaku. Dari persepsi ini memunculkan suatu tanggapan berupa dukungan pada karakrteristik organisasi yang selanjutnya mempengaruhi kinerja pegawai negeri sipil.

Budaya organisasi meresap dalam kehidupan organisasi dan selanjutnya mempengaruhi setiap kehidupan organisasi. Oleh karena itu, Dinas Ketahanan Pangan, Pertanian Dan Perikanan Kabupaten Barito Selatan perlu memperhatikan budaya organisasi karena budaya organisasi akan berpengaruh sangat besar pada aspek-aspek fundamental dari kinerja organisasi. 
Pernyataan tersebut telah diterima dengan luas dan didukung oleh beberapa penelitian yang menghubungkan kinerja dengan budaya organisasi. Jika budaya organisasi merupakan aspek penting dalam meningkatkan kinerja maka budaya organisasi harus dikelola dengan baik. Untuk dapat mengelola organisasi dengan baik diperlukan pengertian yang jelas dan perhatian terhadap budaya organisasi.

Selain Budaya Organisasi, Motivasi juga merupakan faktor yang berpengaruh terhadap kinerja Motivasi Kerja menjadi dasar utama bagi seseorang memasuki suatu organisasi adalah dalam rangka usaha orang yang bersangkutan memuaskan berbagai kebutuhannya. Oleh karena itu kunci keberhasilan seorang pimpinan dalam menggerakkan bawahannya terletak pada Kompetensinya memahami teori Motivasi Kerja sehingga menjadi daya pendorong yang efektif dalam upaya peningkatan Kinerja dalam suatu instansi pemerintahan.

Dinas Ketahanan Pangan,Pertanian Dan Perikanan Kabupaten Barito Selatan juga harus memperhatikan pemberian motivasi kepada pegawainya, motivasi agar diberikan secara cepat dan tepat waktu untuk yang berbentuk finansial, selain berbentuk finansial motivasi non finansial juga harus diberikan seperti pemberian penghargaan, pengembangan dan pemberian tanggung jawab kepada pegawai, semua hal tersebut diberikan agar pegawai termotivasi dan terdorong untuk bekerja denga baik.

Berdasarkan latar belakang masalah yang dikemukakan, penelitian ini akan mengambil judul: "Pengaruh Budaya Organisasi dan Motivasi Kerja Terhadap Kinerja Pegawai Dinas Ketahanan Pangan, Pertanian Dan Perikanan Kabupaten Barito Selatan."

\section{Studi Literatur \\ Budaya Organisasi}

Schein dari MIT, dalam Amstrong (2012:87) menyatakan bahwa:

.Budaya perusahaan sebagai pola asumsi dasar yang ditemukan oleh kelompok tertentu, ditemukan atau dikembangkan untuk mempelajari cara mengatasi masalah-masalah adaptasi dari luar dan cara berintegrasi, yang telah berfungsi dengan baik atau dianggap berlaku, dan karena itu harus diajarkan kepada para anggota baru sebagai yang benar untuk mengundang,memikirkan, dan merumuskan masalah-masalah ini.

Selanjutnya Robbins (2012:112) menyatakan bahwa: .Budaya organisasi (organization culture) sebagai suatu sistem makna bersama yang dianut oleh anggota anggota yang membedakan organisasi tersebut dengan organisasi lain.. Lebih lanjut, Robbins (2012:123) menyatakan bahwa:

Sebuah sistem pemaknaan bersama dibentuk oleh warganya yang sekaligus Menjadi pembeda dengan organisasi lain. Sistem pemaknaan bersama merupakan seperangkat karakter kunci dari nilai-nilai organisasi

Memahami budaya organisasi: Budaya organisasi adalah norma-norma dan kebiasaan yang diterima sebagai suatu kebenaran oleh semua orang dalam organisasi.

Budaya organisasi menjadi acuan bersama diantara manusia dalam melakukan interaksi dan organisasi. Pendapat lain dikemukakan Susanto (2013:86) yang menyatakan bahwa:

Budaya organisasi adalah sebagai nilai-nilai yang menjadi pedoman sumber daya manusia untuk menghadapi permasalahan eksternal dan usaha penyesuaian integrasi ke dalam perusahaan sehingga masing-masing anggota organisasi harus memahami nilai-nilai yang ada dan bagaimana mereka harus bertindak dan berperilaku. 
Kotter dan Hesket dalam Soetjipto (2012:54) berpendapat bahwa budaya organisasi pada dasarnya merupakan norma-norma dan nilai-nilai yang berlaku di dalam organisasi, contohnya: kesigapan dalam memberikan pelayanan kepada para pelanggan, sedangkan nilai mencerminkan keyakinan atau kepercayaan mereka akan hal-hal tertentu yang mampu mendatangkan kesuksesan, contohnya: perhatian yang besar kepada kepuasan pelanggan. Jika keduanya dibandingkan, norma relatif lebih kasat mata dan lebih mudah untuk dirubah.

Sedangkan Hofstede (2012:99) menyatakan bahwa Budaya organisasi sebagai konstruksi dari dua tingkat karakteristik, yaitu karakteristik organisasi yang kelihatan (observable) dan yang tidak kelihatan (unobservable). Pada level observable, budaya organisasi mencakup beberapa aspek organisasi seperti arsitektur, seragam, pola perilaku, peraturan, bahasa, dan seremoni yang dilakukan perusahaan.

Sementara pada level (unabsorvable), budaya organisasi mencakup shared value, norma-norma, kepercayaan, asumsi-asumsi para anggota organisasi untuk mengelola masalah dan keadaan-keadaan sekitarnya.

Perusahaan yang berorientasi pada kepentingan pasar memerlukan budaya dukungan (support culture) dan budaya prestasi (achievement culture) sebagai cara meningkatkan motivasi dan komitmen karyawan. Budaya organisasi yang efektif adalah budaya organisasi yang mengakar kuat dan dalam. Di perusahaan yang berbudaya demikian, hampir semua individunya menganut nilai-nilai yang seragam dan konsisten.

Setiap organisasi atau bahkan setiap bagian dalam suatu organisasi menunjukkan symbol dan ritual yang berbeda karena di dalamnya terdiri dari berbagai individu dengan latar belakang dan pengalaman yang beragam. Namun demikian budaya organisasi memiliki sejumlah disemsi yang berguna untuk memudahkan setiap upaya pengidentifikasian karakteristik budaya tertentu dalam organisasi. Hofstede (2012:75) menyatakan bahwa ada 6 (enam) dimensi budaya organisasi yang dapat ditemukan pada berbagai organisasi, yaitu:

a. Process-oriented versus resuls-oriented

b. Employee-oriented versus job-oriented

c. Parochial versus professional

d. Open system versus closed system

e. Tight control versus loose control

f. Pragmatic versus normative emphasis towards clients

Dimensi keenam dalam budaya organisasi ini utamanya berkaitan dengan topik terkini dalam bisnis yaitu tentang orientasi perusahaan pada pelanggan. Perusahaan yang berbeda pada tekanan kompetensi yang ketat cenderung berbudaya pragmatis, sebaliknya organisasi yang bersifat monopolistis di mana tidak terdapat persaingan dalam bisnis cenderung bersifat normatif.

Berdasarkan pengertianpengertian di atas, budaya organisasi dapat dikatakan sebagai aturan main yang ada di dalam perusahaan yang akan menjadi pegangan dari sumber daya manusia dalam menjalankan kewajibannya dan nilai-nilai untuk berperilaku dalam organisasi. Nilai-nilai tersebut tercermin dalam perilaku dan sikap mereka sehari-hari selama mereka berada dalam organisasi tersebut dan sewaktu mewakili organisasi berhadapan dengan pihak luar, Dengan kata lain, budaya organisasi mencerminkan cara karyawan melakukan sesuatu (membuat keputusan, melayani orang, dsb). Misalnya saja cara petugas penerima tamu, kondisi ruangan, pakaian seragam, cara menerima telepon, dan sebagainya. 


\section{Karakteristik Budaya Organisasi}

Robbins (2012:132) menyatakan ada 10 karakteristik yang apabila dicampur dan dicocokkan, dengan budaya organisasi. Kesepuluh karakteristik budaya organisasi tersebut sebagai berikut:

1. Inisiatif Individual

2. Toleransi terhadap Tindakan Berisiko

3. Pengarahan

4. Integrasi

5. Dukungan Manajemen

6. Kontrol

7. Identitas

8. Sistem Imbalan

9. Toleransi terhadap Konflik

10. Pola Komunikasi

\section{Fungsi Budaya Organisasi}

Budaya organisasi memiliki beberapa fungsi dan organisasi, yaitu:

1. Memberi batasan untuk mendefinisikan peran, sehingga memperhatikan perbedaan yang jelas antarorganisasi;

2. Memberikan pengertian identitas terhadap anggota organisasi;

3. Memudahkan munculnya komitmen terhadap sesuatu yang lebih besar dibanding minat anggota organisasi secara perorangan;

4. Menunjukkan stabilitas sistem sosial;

5. Memberikan pengertian dan mekanisme pengendalian yang dapat dijadikan pedoman untuk membentuk sikap serta perilaku para anggota organisasi;

6. Membantu para anggota organisasi mengatasi ketidakpastian, karena pada akhirnya budaya organisasi berperan untuk membentuk pola pikir dan perilaku anggota organisasi (Robbins, 2012:99).

Memperhatikan fungsi dan manfaat budaya tersebut di atas, maka budaya dalam suatu organisasi sangat penting. Oleh karena itu budaya senantiasa dipelihara dan dikembangkan karena disadari budaya merupakan alat (tool) dalam setiap melaksanakan kegiatan-kegiatan organisasi serta menjadi stimulasi untuk meningkatkan kinerja organisasi.

\section{Pengertian Motivasi}

Motivasi membicarakan tentang bagaimana cara mendorong semangat kerja sesorang, agar mau bekerja dengan memberikan secara optimal kemampuan dan keahliannya guna mencapai tujuan organisasi. Motivasi menjadi penting karena dengan motivasi diharapkan setiap karyawan mau bekerja keras dan antusias untuk mencapai produktivitas kerja yang tinggi. Perilaku seseorang dipengaruhi dan dirangsang oleh keinginan, pemenuhan kebutuhan serta tujuan dan kepuasannya. Rangsangan timbul dari dalam dan luar. Rangsangan ini akan menciptakan dorongan pada seseorang untuk melakukan aktivitas. Seperti telah dikutip di depan bahwa pengertian motivasi, menurut berelson dan steiner dalam Sunyoto (2012: 11) adalah suatu usaha sadar untuk mempengaruhi perilaku seseorang supaya mengarah tercapainya tujuan organisasi.

Selain pendapat diatas ada beberapa pendapat yang memberikan pengertian yang sama atau hamper sama yaitu : " menurut Casio dalam Hasibuan (2013:95) yang dikutip Sunyoto (2012: 11) motivasi adalah suatu kekuatan yang dihasilkan dari keinginan seseorang untuk memuaskan kebutuhannya, missal : rasa lapar, haus, dan dahaga".

\section{Teori - Teori Motivasi}

Rivai (2011:458), mengatakan bahwa terdapat beberapa teori motivasi adalah sebagai berikut :

\section{Hierarki Teori Kebutuhan (Hierarchical of Needs Theory)}

Menurut Abraham Maslow bahwa pada setiap diri manusia itu terdiri atas lima kebutuhan yaitu Kebutuhan Fisik terdiri dari kebutuhan akan perumahan, makanan, minuman, dan kesehatan. Kebutuhan rasa aman 
dalam dunia kerja, pegawai menginginkan adanya jaminan sosial tenaga kerja, pensiun, perlengkapan keselamatan kerja, dan kepastian dalam status kepegawaian. Kebutuhan sosial, kebutuhan ini berkaitan dengan menjadi bagian dari orang lain, dicintai orang lain, dan mencintai orang lain. Kebutuhan pengakuan, kebutuhan yang berkaitan tidak hanya menjadi bagian dari orang lain. Sedangkan kebutuhan untuk aktualisasi diri, yaitu kebutuhan untuk menggunakan kemampuan, skill, dan potensi.

2. Teori Kebutuhan McClelland's (McClelland's Theory of Needs)

McClelland theory of needs memfokuskan kepada tiga hal, yaitu:

a. Kebutuhan dalam mencapai kesuksesan: kemampuan untuk mencapai hubungan kepada standar perusahaan yang telah ditentukan juga perjuangan karyawan untuk menuju keberhasilan.

b. Kebutuhan dalam kekuasaan atau otoritas kerja: kebutuhan untuk membuat orang berperilaku dalam keadaan yang wajar dan bijaksana didalam tugasnya masing-masing

c. Kebutuhan untuk berafiliasi: hasrat untuk bersahabat dan mengenal lebih dekat rekan kerja.

\section{Teori X dan Y Mc. Gregor}

Teori X dan Y, Douglas McGregor yang dikutip oleh Hasibuan (2003:160) mengajukan dua pandangan yang berbeda tentang manusia, negatif dengan tanda label $\mathrm{x}$ dan positif dengan tanda label y.

1) Teori $X$ (negatif) merumuskan asumsi-asumsi sebagai berikut:

a. Rata-rata karyawan malas dan tidak suka bekerja.

b. Umumnya karyawan tidak berambisi mencapai prestasi yang optimal dan selalu menghindari tanggung jawabnya dengan cara mengkambinghitamkan orang lain.

c. Karyawan lebih suka dibimbing, diperintah, dan diawasi dalam melaksanakan pekerjaannya.

d. Karyawan lebih mementingkan diri sendiri dan tidak memperdulikan tujuan organisasi.

2) Sedangkan Teori Y (positif) memiliki asumsi-asumsi sebagai berikut :

a. Rata-rata karyawan rajin dan menganggap sesungguhnya bekerja, sama wajarnya dengan bermain-main dan beristirahat. Pekerjaan tidak perlu dihindari dan dipaksakan, bahkan banyak karyawan tidak betah dan merasa kesal tidak bekerja.

b. Lazimnya karyawan dapat memikul tanggung jawab dan berambisi untuk maju dengan mencapai prestasi kerja yang optimal.

c. Karyawan selalu berusaha mencapai sasaran organisasi dan mengambangkan dirinya untuk mencapai sasran itu. Organisasi seharusnya memungkinkan karyawan mewujudkan potenisnya sendiri dengan memberikan sumbangan pada tercapainya sasaran perusahaan.

\section{ERG Theory / Teori Clayton Alderfer} (Existence, Relatedness, Growth Theory)

Teori ini dikemukakan oleh Clayton Alderfer yang dikutip oleh Mangkunegara (2012:98), yang sebetulnya tidak jauh berbeda dengan teori dari Abraham Maslow. Teori ini mengemukakan bahwa ada tiga kelompok kebutuhan manusia, yaitu: 
a. Existence needs, kebutuhan ini berhubungan dengan fisik dari eksistensi pegawai, seperti makan, minum, pakaian, bernapas, gaji, keamanan kondisi kerja, fringe benefits.

b. Relatedness needs, kebutuhan interpersonal, yaitu kepuasan dalam berinteraksi dalam lingkungan kerja.

c. Growth needs, kebutuhan untuk mengembangkan dan meningkatkan pribadi. Hal ini berhubungan dengan kemampuan dan kecakapan pegawai.

\section{Teori Herzberg}

Teori Herzberg disebut sebagai "teori motivasi dan hygiene". Penelitian yang dilakukan dalam pengembangan teori ini dikaitkan dengan pandangan para karyawan tentang pekerjaannya. Faktor-faktor yang mendorong aspek motivasi menurut Frederik Herzberg ialah keberhasilan, pengakuan, sifat pekerjaan yang menjadi tanggung jawab seseorang, kesempatan meraih kemajuan dan pertumbuhan. Sedangkan faktorfaktor hygiene yang menonjol ialah kebijaksanaan perusahaan. Kondisi pekerjaan, upah dan gaji, hubungan dengan rekan sekerja, kehidupan pribadi, hubungan dengan para bawahan, status dan keamanan.

\section{Faktor - Faktor Motivasi}

Sunyoto (2012: 13) Faktor - faktor motivasi ada enam yaitu :
a) Promosi
b) Prestasi kerja
c) Pekerjaan itu sendiri
d) Penghargaan
e) Pengakuan
f) Keberhasilan dalam bekerja

\section{Indikator Motivasi}

Berikut teori motivasi "dua faktor" menurut Herzberg yang dapat dijadikan sebagai acuan guna mengukur motivasi yang dikutip oleh Siagian (2012:164) adalah sebagai berikut :

Tabel 1 Teori Motivasi "Dua Faktor" Menurut Herzberg

\begin{tabular}{|l|l|}
\hline \multicolumn{1}{|c|}{ Faktor Eksterinsik } & \multicolumn{1}{c|}{ Faktor Interinsik } \\
\hline 1. Kebijaksanaan dan Administrasi & 1. Keberhasilan \\
2. Supervisi & 2. Pengakuan / Penghargaan \\
3. Gaji / Upah & 3. Pekerjaan itu sendiri \\
4. Hubungan antar pribadi & 4. Tanggung jawab \\
5. Kondisi Kerja & 5. Pengembangan \\
\hline
\end{tabular}

Sumber : Siagian (2012:164)

Herzberg memandang bahwa kepuasan kerja berasal dari keberadaan motivator intrinsik dan bahwa ketidakpuasan kerja berasal dari ketidakberadaan faktor-faktor ekstrinsik.

Dengan demikian seseorang yang terdorong secara intrinsik akan menyenangi pekerjaannya, memungkinkan menggunakan kreatifitas dan inovasi dan tidak perlu diawasi dengan ketat. Kepuasan disini tidak dikaitkan dengan perolehan hal - hal yang bersifat materi. Sebaliknya, mereka yang terdorong oleh faktor - faktor ekstrinsik cenderung melihat kepada apa yang diberikan oleh organisasi kepada mereka dan kinerjanya diarahkan kepada perolehan hal - hal yang diinginkannya dari organisasi. Menurut herzberg faktor ekstrinsik tidak akan mendorong para karyawan untuk berforma baik, akan tetapi jika faktor - faktor ini dianggap tidak memuaskan dalam berbagai hal seperti gaji tidak memadai, kondisi kerja tidak menyenangkan, hal tersebut dapat menjadi sumber ketidakpuasan potensial.

\section{Kinerja Pegawai}

Kinerja karyawan yang dinyatakan Mangkunegara (2012:55) adalah hasil kerja secara kualitas dan kuantitas yang dicapai oleh seseorang karyawan dalam melaksanakan tugasnya sesuai dengan tanggung jawab yang diberikan kepadanya.

Oleh karena itu output baik kualitas maupun kuantitas yang dicapai sumber daya manusia persatuan periode waktu dalam melaksanakan tugas kerjanya sesuai 
dengan tanggung jawab yang diberikan kepadanya.

Pekerjaan hampir selalu memiliki lebih dari satu kriteria atau dimensi untuk dinilai, dan ini berarti bahwa si karyawan mungkin berKinerja lebih baik dalam satu kriteria dibandingkan kriteria lainnya. Beberapa kriteria mungkin memiliki nilai lebih penting daripada kriteria lainnya. Pembobotan adalah suatu cara untuk menunjukkan hal ini. Beberapa perkantoran atau Dinas lainnya merupakan bagian pekerjaan yang memiliki bobot yang lebih besar dibandingkan dengan penelitian atau pengabdian.

Pada saat mengukur kinerja, adalah penting menentukan kriteria yang relevan, Umumnya, kriteria itu relevan ketika difokuskan pada aspek yang paling penting dari pekerjaan si karyawan. Sebagai contoh, menilai seorang petugas pelayanan kepuasan konsumen dalam suatu perusahaan dari .penampilan. tentu saja kurang relevan dibandingkan dengan jumlah telepon yang ditanganinya. Contoh ini menekankan bahwa kriteria pekerjaan yang terpenting harus diidentifikasikan dan dikaitkan dengan Job Description, Job Spesification.

Faktor-faktor yang mempengaruhi Kinerja menurut Sedarmayanti (2012:91) antara lain: 1). Sikap mental (motivasi kerja, disiplin kerja, etika kerja); 2). Pendidikan; 3). Keterampilan; 4). Manajemen kepemimpinan; 5) Tingkat penghasilan; 6) Gaji dan kesehatan; 7) Jaminan sosial; 8). Iklim kerja; 9). Sarana prasarana; 10). Teknologi; 11). Kesempatan berprestasi.

\section{Faktor Yang Mempengaruhi Kinerja}

Masalah kinerja selalu mendapat perhatian dalam manajemen karena sangat berkaitan dengan produktivitas lembaga atau organisasi. Kinerja karyawan adalah yang mempengaruhi seberapa banyak mereka memberikan kontribusi kepada organisasi yang antara lain termasuk: kuantitas output, kualitas output, jangka waktu output, kehadiran di tempat kerja, dan sikap kooperatif. Tampaknya dimensi lain dari Kinerja mungkin tepat untuk pekerjaan-pekerjaan tertentu, tetapi yang didata ini adalah yang paling umum, yang mengidentifikasikan elemen-elemen yang paling penting suatu pekerjaan.

Menurut Gibson (2012:88), faktorfaktor individual yang mempengaruhi kinerja meliputi kemampuan fisik, kemampuan mental (intelegensi) dan keterampilan, faktor demografis (misal umur, jenis kelamin, ras, etnik, dan budaya) serta variabel-variabel psikologis (persepsi, atribusi, sikap, dan kepribadian). Variabel lingkungan pekerjaan (job design, peraturan dan kebijakan, kepemimpinan, sumber daya, penghargaan serta sanksi) dan non pekerjaan (keluarga, keadaan ekonomi serta hobi) juga berpengaruh pada perilaku bekerja yang akhirnya membentuk Kinerja seseorang. Kinerja merupakan kuantitas dan kualitas pekerjaan yang diselesaikan oleh individu, maka kinerja merupakan output pelaksanaan tugas. Kinerja mempunyai hubungan yang erat dengan masalah produktivitas, karena merupakan indicator dalam menentukan bagaimana usaha untuk mencapai tingkat produktivitas yang tinggi dalam suatu organisasi.

Hasibuan (2012:87) menyatakan bahwa: produktivitas adalah perbandingan antara keluaran (output) dengan masukan (input). Faktor-faktor yang mempengaruhi Kinerja menurut Sedarmayanti (2012:110) antara lain: .1). Sikap mental (motivasi kerja, disiplin kerja, etika kerja); 2). Pendidikan; 3). Keterampilan; 4). Manajemen kepemimpinan; 5). Tingkat penghasilan; 6) Gaji dan kesehatan; 7). Jaminan sosial; 8). Iklim kerja; 9) Sarana prasarana; 10). Teknologi; 11). Kesempatan berprestasi.

\section{Pengukuran Kinerja Pegawai}


Menurut Bernandin dan Russel dalam Gomes (2012:135) mengemukakan ukuran-ukuran dari kinerja pegawai yaitu sebagai berikut:

1. Quantity of work yaitu jumlah kerja yang dilakukan dalam suatu periode yang ditentukan.

2. Quality of work yaitu kualitas kerja yang dicapai berdasarkan syarat-syarat kesesuaian dan kesiapannya.

3. Job Knowledge yaitu luasnya pengetahuan mengenai pekerjaan dan keterampilannya.

4. Creativeness yaitu keaslian gagasangagasan yang dimunculkan dan tindakan-tindakan untuk menyelesaikan persoalan-persoalan yang timbul.

5. Cooperation yaitu kesediaan untuk bekerja sama dengan orang lain atau sesama anggota organisasi.

6. Dependability yaitu kesadaran untuk dapat dipercaya dalam hal kehadiran dan penyelesaian kerja.

7. Initiative yaitu semangat untuk melaksanakan tugas-tugas baru dan dalam memperbesar tanggungjawabnya.

8. Personal qualities yaitu menyangkut keperibadian, kepemimpinan, keramahtamahan dan integritas pribadi.

Kesetiaan Pegawai dapat dilihat dari tekad dan kesanggupan menaati, melaksanakan, dan mengamalkan sesuatu yang ditaati dengan penuh kesadaran dan tanggungjawab. Sehingga menghasilkan prestasi kerja yang maksimal. Prestasi kerja merupakan kinerja yang dicapai oleh seorang pegawai dalam melaksanakan tugas dan pekerjaan yang diberikan kepadanya.

Kinerja pegawai dinilai berdasarkan kedisiplinannya dalam menjalankan tugasnya sebagai Pegawai yaitu kesadaran dan kesediaan seorang Pegawai untuk menghormati, menghargai, mematuhi dan menaati peraturan-peraturan yang berlaku, baik yang tertulis maupun tidak tertulis serta sanggup menjalankanya.

Selain kreativitas pegawai juga perlu dibangun. Kreativitas ini berupa kemampuan pengetahuan yang dimiliki karyawan dan juga kemampuan untuk mengemukakan atau menciptakan suatu program kerja baru dalam menghadapi tantangan kerja, baik secara individu maupun dalam tim. Sehingga pegawai juga dituntut untuk mempunyai kemampuan bekerjasama dengan orang lain dalam menyelesaikan suatu tugas dan pekerjaan yang telah ditetapkan, sehingga mencapai daya guna dan hasil guna yang sebesarbesarnya. Pekerjaan yang dilakukan pegawai harus berjalan secara efektif dan efisien agar dapat meningkatkan kinerjanya, dan yang terpenting dalam menyelesaikan tugas dan pekerjaan yang dieserahkan kepadanya Pegawai terseut mempunyai kesanggupan untuk menyelesaikan dengan sebaik-baiknya dan tepat waktu sert berani memikul resiko atas keputusan yang telah diambilnya.

\section{Motode Penelitian}

Jenis penelitian yang digunakan dalam penelitian ini adalah metode survei. Menurut Umar (2012:48) bahwa metode survei adalah riset yang diadakan untuk memperoleh faktor-faktor tentang gejalagejala atas permasalahan yang timbul. Kegiatan penelitian ini dilakukan pada Pegawai Dinas Ketahanan Pangan, Pertanian dan Perikanan Kabupaten Barito Selatan.

Penelitian ini bersifat kuantitatif yang bermaksud menjelaskan hubungan kausal antar variabel melalui pengujian hipotesis. Sehingga penelitian ini termasuk dalam jenis eksplanatori yaitu jenis penelitian yang bertujuan mencari potensipotensi hubungan-hubungan antara satu variabel dengan variabel lainnya atau bagaimana suatu variabel mempengaruhi variabel lainnya. Umar (2012:51) 


\section{Populasi dan Sampel}

\section{Populasi}

Populasi dalam penelitian ini adalah seluruh Pegawai Dinas Ketahanan Pangan, Pertanian dan Perikanan Kabupaten Barito Selatan yang berjumlah 315 (tiga ratus lima belas) orang.

\section{Sampel}

Populasi dalam penelitian ini lebih dari 100 orang, maka untuk mempersingkat waktu dan dana penelitian untuk itu dilakukan pengambilan sampel secara acak berdasarkan rumus Slovin (dalam Umar, 2012: 120). seperti di bawah ini:

$$
\mathbf{n}=\frac{\mathrm{N}}{1+\mathrm{N} \mathrm{e} 2}
$$

di mana:

$\begin{array}{lll}1 & = & \text { Konstanta } \\ \mathrm{n} & = & \text { Ukuran sampel } \\ \mathrm{N} & = & \text { Ukuran populasi } \\ \mathrm{e} 2 & = & \text { Kelonggaran } \\ & & \text { ketidaktelitian karena } \\ & \text { kesalahan pengambilan } \\ & \text { sampel yang dapat ditolerir }\end{array}$

Diketahui :

1 = konstanta

$\mathrm{n}=$ ukuran sampel

$\mathrm{N}=315$

$\mathrm{e} 2=10 \%$

$\mathrm{N}=\frac{315}{1+315(0,010)^{2}}=\frac{315}{4,15}=75,9=76$

Berdasarkan hasil perhitungan diatas menggunakan taraf kepercayaan $90 \%$ maka sampel dalam penelitian ini berjumlah 76 (tujuh puluh enam) orang pegawai Dinas Ketahanan Pangan, Pertanian dan Perikanan Kabupaten Barito Selatan.

\section{Jenis dan Sumber Data Jenis Data}

\section{a. Data Kualitatif}

Pendekatan

kualitatif menekankan pada makna dan pemahaman dari dalam (verstehen), penalaran, definisi suatu situasi tertentu (dalam konteks tertentu), lebih banyak meneliti hal-hal yang berhubungan dengan kehidupan sehari-hari. Pendekatan kualitatif, lebih lanjut, mementingkan pada proses dibandingkan dengan hasil akhir; oleh karena itu urut-urutan kegiatan dapat berubah-ubah tergantung pada kondisi dan banyaknya gejala-gejala yang ditemukan. Tujuan penelitian biasanya berkaitan dengan hal-hal yang bersifat praktis

\section{b. Data Kuantitatif}

\section{Pendekatan kuantitatif} mementingkan adanya variabelvariabel sebagai obyek penelitian dan variabel-variabel tersebut harus didefenisikan dalam bentuk operasionalisasi variabel masingmasing dan pemahaman dari luar (outward). Reliabilitas dan validitas merupakan syarat mutlak yang harus dipenuhi dalam menggunakan pendekatan ini karena kedua elemen tersebut akan menentukan kualitas hasil penelitian dan kemampuan replikasi serta generalisasi penggunaan model penelitian sejenis. Selanjutnya, penelitian kuantitatif memerlukan adanya hipotesis dan pengujiannya yang kemudian akan menentukan tahapantahapan berikutnya, seperti penentuan teknik analisis dan formula statistik yang akan digunakan. Juga, pendekatan ini lebih memberikan makna dalam hubungannya dengan penafsiran angka statistik bukan makna secara kebahasaan dan kulturalnya.

\section{Sumber Data}

\section{Data primer}

Data primer merupakan data 
penelitian yang diperoleh secara langsung dari sumber asli (tidak melalui perantara), dimana data primer ini dapat berupa opini subjek (orang) secara individual atau kelompok hasil observasi, kejadian atau kegiatan (Supomo:2012:146)

\section{Data Sekunder}

Data sekunder adalah data yang tersedia sebelumnya, diperoleh dari pihak lain berasal dari buku - buku, literature, artikel, dan tulisan - tulisan ilmiah. (Umar, 2012:84) sumber data sekunder penelitian ini adalah buku literature, majalah, internet dan brosur yang lainnya.

\section{Teknik Pengumpulan Data}

Teknik pengumpulan data dalam penelitian ini adalah:

1. Studi pustaka, dimaksudkan untuk mendapatkan kajian dasar teoritik yang relevan dengan masalah yang diteliti.

2. Kuisioner, pengumpulan data dengan menggunakan daftar pernyataan yang digunakan untuk mengetahui persepsi responden terhadap beberapa variabel yang dipertimbangkan dalam kompetensi dan kinerja pegawai.

3. Wawancara, pengumpulan data dengan melakukan tanya jawab secara langsung dengan nara sumber agar mendapatkan informasi yang tidak terakomodasi dari kuisioner.

4. Teknik dokumentasi dari dokumen yang ada di Dinas Ketahanan Pangan, Pertanian dan Perikanan Kabupaten Barito Selatan yang berkaitan dan diperlukan dalam penelitian ini

\section{Teknik Analisis Data \\ Instrumen Penelitian}

Penelitian ini menggunakan instrumen kuesioner yang didalamnya terdapat sejumlah pertanyaan yang digunakan untuk memperoleh tanggapan dan informasi dari responden.

\section{a. Pengukuran Kuesioner}

Berdasarkan

Definisi

Operasional Variabel diatas pengukuran variabel dalam penelitian ini menggunakan skala likert. Skala likert digunakan untuk mengukur sikap, pendapat, dan persepsi seseorang atau sekelompok orang tentang fenomena sosial. Skala ini meminta responden menunjukan tingkat persetujuan atau ketidak setujuannya terhadap serangkaian pertanyaan tentang suatu objek (Sugiyono, 2006). Alat ukur yang digunakan adalah kuesioner yang akan diuji validitas dan reliabilitasnya. Kinerja pegawai akan diukur dari pengaruh Budaya Organisasi dan Motivasi Kerja. Untuk masing-masing responden mempunyai 5 alternatif jawaban (Skala Likert).

\section{Uji Validitas Instrumen}

Teknik pengujian validitas menggunakan teknik korelasi product moment dari pearson dengan tingkat signifikansi $5 \%$ untuk menge-tahui keeratan pengaruh antara variabel bebas dengan variabel terikat dengan cara mengkorelasikan antara skor item pernyataan terhadap skor total. Apabila nilai total pearson correlation $>0,3$, atau probabilitas kurang dari 0,05 maka item tersebut valid (Arikunto, 2012:146 ).

\section{c. Uji Reliabilitas Instrumen}

Teknik pengujian reliabilitas menggunakan koefisien alpha cronbach dengan taraf nyata 5\%, Jika koefisien korelasi lebih besar dari nilai kritis atau jika nilai alpha cronbach lebih besar daripada 0,6 maka item tersebut dinyatakan reliabel. Koefisien alpha kurang dari 0,6 menunjukkan reliabilitas yang buruk, angka sekitar 0,7 menunjukkan reliabilitas dapat diterima dan angka di atas 0,8 menunjukkan reliabilitas yang baik. (Sekaran 2012:311) 


\section{Uji Asumsi Klasik}

Untuk memastikan apakah variabelvariabel penelitian dapat dianalisis dengan menggunakan Regresi Linier Berganda atau tidak, maka diperlukan suatu uji asumsi klasik sebagai persyaratan analisis regresi berganda. Variabel-variabel tersebut harus memenuhi syarat-syarat sebagai berikut:

\section{Uji Multikolinieritas}

Uji multikolinieritas ini digunakan untuk mengetahui ada tidaknya korelasi antara variabel independen. Jika terjadi korelasi, maka dinamakan terdapat problem multikolinieritas. Untuk3.6. mengetahui ada tidaknya multikolinieritas antar variabel, dapat dilihat dari Variable Inflation Factor (VIF) dari masingmasing variabel bebas terhadap variabel terikat. Menurut Santoso (2005: 357), jika nilai VIF tidak lebih besar dari 5 maka dalam model tidak terdapat multikolinieritas.

\section{Uji Heteroskedastisitas}

Uji heteroskedastisitas bertujuan untuk menguji apakah dalam sebuah model regresi terjadi3.6. ketidaksamaan varian dari residual dari suatu pengamatan lainnya. Jika varian dari pengamatan lainnya tetap, maka disebut homoskedastisitas. Sedangkan apabila variannya berbeda dari satu pengamatan ke pengamatan lainnya disebut dengan gejala heteroskedastisitas. Untuk mengetahui ada atau tidaknya gejala heteroskedastisitas adalah dengan melihat ada tidaknya pola tertentu pada grafik scatter plot. Apabila tidak ada pola yang jelas atau pola tertentu serta titik menyebar di atas dan di bawah angka 0 pada sumbu Y, maka tidak terjadi heteroskedastisitas.

\section{Uji Normalitas}

Uji Normalitas dilakukan dengan tujuan untuk mengetahui apakah dalam sebuah model regresi baik itu variabel terikat maupun variabel bebas secara terpisah atau secara bersamaan keduanya mempunyai distribusi normal atau tidak.
Deteksi normalitas dilakukan dengan melihat penyebaran data (titik) pada sumbu diagonal dari grafik. Dasar pengambilan keputusan yang digunakan:

a) Jika data menyebar di sekitar garis diagonal dan mengikuti arah garis diagonal, maka model regresi memenuhi asumsi normalitas.

b). Jika data menyebar jauh dari garis diagonal, maka model regresi tidak memenuhi asumsi normalitas (Santoso, 2008:214).

\section{Analisis Deskriptif}

Tujuan analisis deskriptif adalah untuk menjelaskan/mendiskripsikan karakteristik responden maupun variabel yang diteliti. Bentuknya tergantung dari jenis data. Untuk data katagorik hanya dapat menjelas-kan angka/nilai jumlah dan persentase masing-masing kelompok, sedangkan data numerik digunakan nilai mean (rata-rata), median, standar deviasi, dsb. (Hastono, 2012: 62-69).

\section{Analisis Regresi Linier Berganda}

Penelitian ini juga menggunakan analisis inferensial untuk menguji pengaruh Budaya Organisasi dan Motivasi Kerja terhadap variabel kinerja pegawai dan menguji hipotesis yang telah dirumuskan. Model analisis yang digunakan adalah regresi linier berganda dengan menggunakan bantuan perangkat lunak komputer (software) program SPSS (Statistical Product and Service Solutions) versi 21.0 for Windows, dengan rumus sebagai berikut :

$$
\begin{aligned}
& \mathrm{Y}=\beta 0+\beta 1 \mathrm{X} 1+\beta 2 \mathrm{X} 2+\varepsilon \\
& \text { Keterangan : } \\
& \mathrm{Y}=\text { Kinerja pegawai } \\
& \beta 0=\text { Konstanta (intersep) } \\
& \beta 1 . . \beta 2=\text { Koefisien regresi } \\
& \mathrm{X} 1=\text { Budaya Organisasi } \\
& \text { X2 = Motivasi Kerja }
\end{aligned}
$$


$\varepsilon \quad=$ Kesalahan pengganggu

\section{Pengujian Hipotesis}

\section{Uji Hipotesis I (Uji t)}

Uji statistik $\mathrm{t}$ digunakan untuk mengetahui seberapa jauh pengaruh satuvariabel independen secara individual dalam menjelaskan variasi variabel dependen (Ghozali, 2012). Apabila nilai $t_{\text {hitung }}>t_{\text {tabel }}$ dan probabilitas signifikansi $<0.05$, maka suatu variabelindependen merupakan penjelas yang signifikan terhadap variabel dependen

\section{Uji Hipotesis II (Uji F)}

Uji statistik F digunakan untuk mengetahui apakah semua variabelindependen yang dimasukkan dalam model regresi mempunyai pengaruh secara bersama-sama (simultan) terhadap variabel dependen (Ghozali, 2012). Apabila nilai $f_{\text {hitung }}>$ $\mathrm{f}_{\text {tabel }}$ dan nilai probabilitas signifikansi < 0.05 , maka variabel independen secara bersama-samamempengaruhi variabel dependen.

3. Uji Hipotesis III (Variabel Dominan)

Dari variabel yang bermakna, dipilih variabel yang dominan, Untuk mengetahui seberapa besar kontribusi masing-masing variabel bebas dan yang paling menentukan (dominan) pengaruhnya terhadap variabel terikat suatu model regresi linier, maka digunakan koefisien Beta (Beta Coefficient) setiap variabel yang distandarisasi (standardized cofficient). Nilai beta $(\beta)$ terbesar menunjukkan bahwa variabel bebas tersebut mempunyai pengaruh yang dominan terhadap variabel terikat. (Sritua, 2012:12).

\section{Hasil Penelitian dan Pembahasan}

\section{a. Uji Validitas}

Valid atau tidaknya suatu instrumen dapat diketahui dengan membandingkan indeks korelasi product moment pearson dengan level signifikansi $5 \%$ dan $\mathrm{r}$ 0,03. Bila signifikansi hasil korelasi lebih kecil dari $0,05(5 \%)$ dan $r>0,03$ maka dinyatakan valid dan sebaliknya apabila signifikansi hasil korelasi lebih besar dari $0,05(5 \%)$ dan $<0,03$ maka dinyatakan tidak valid, Adapun hasil uji validitas dan reliabilitas adalah :

Tabel 2 Rekapitulasi Hasil Uji Validitas Instrumen Penelitian

\begin{tabular}{|c|c|c|c|c|c|c|}
\hline Variabel & $\begin{array}{c}\text { Item } \\
\text { Pernyataan }\end{array}$ & $\mathrm{r}$ & r syarat & Sig & $\begin{array}{c}\text { Sig } \\
\text { Syarat }\end{array}$ & Ket \\
\hline \multirow{10}{*}{$\begin{array}{c}\text { Budaya } \\
\text { Organisasi } \\
\text { (X1) }\end{array}$} & $\mathrm{X} 1.1$ & 0,767 & 0,3 & 0,000 & 0,05 & Valid \\
\hline & $\mathrm{X} 1.2$ & 0,910 & 0,3 & 0,000 & 0,05 & Valid \\
\hline & $\mathrm{X} 1.3$ & 0,878 & 0,3 & 0,000 & 0,05 & Valid \\
\hline & X 1.4 & 0,902 & 0,3 & 0,000 & 0,05 & Valid \\
\hline & $\mathrm{X} 1.5$ & 0,891 & 0,3 & 0,000 & 0,05 & Valid \\
\hline & X1.6 & 0,870 & 0,3 & 0,000 & 0,05 & Valid \\
\hline & X 1.7 & 0,886 & 0,3 & 0,000 & 0,05 & Valid \\
\hline & X1.8 & 0,626 & 0,3 & 0,000 & 0,05 & Valid \\
\hline & X1.9 & 0,873 & 0,3 & 0,000 & 0,05 & Valid \\
\hline & $\mathrm{X} 1.10$ & 0,859 & 0,3 & 0,000 & 0,05 & Valid \\
\hline \multirow{15}{*}{$\begin{array}{l}\text { Motivasi } \\
\text { (X2) }\end{array}$} & $\mathrm{X} 2.1$ & 0,750 & 0,3 & 0,000 & 0,05 & Valid \\
\hline & $\mathrm{X} 2.2$ & 0,787 & 0,3 & 0,000 & 0,05 & Valid \\
\hline & X2.3 & 0,838 & 0,3 & 0,000 & 0,05 & Valid \\
\hline & X2.4 & 0,851 & 0,3 & 0,000 & 0,05 & Valid \\
\hline & $X 2.5$ & 0,829 & 0,3 & 0,000 & 0,05 & Valid \\
\hline & X2.6 & 0,838 & 0,3 & 0,000 & 0,05 & Valid \\
\hline & $\mathrm{X} 2.7$ & 0,904 & 0,3 & 0,000 & 0,05 & Valid \\
\hline & $\mathrm{X} 2.8$ & 0,904 & 0,3 & 0,000 & 0,05 & Valid \\
\hline & X2.9 & 0,902 & 0,3 & 0,000 & 0,05 & Valid \\
\hline & $\mathrm{X} 2.10$ & 0,864 & 0,3 & 0,000 & 0,05 & Valid \\
\hline & $\mathrm{X} 2.11$ & 0,883 & 0,3 & 0,000 & 0,05 & Valid \\
\hline & $\mathrm{X} 2.12$ & 0,864 & 0,3 & 0,000 & 0,05 & Valid \\
\hline & X2.13 & 0,848 & 0,3 & 0,000 & 0,05 & Valid \\
\hline & $\mathrm{X} 2.14$ & 0,808 & 0,3 & 0,000 & 0,05 & Valid \\
\hline & $\mathrm{X} 2.15$ & 0,776 & 0,3 & 0,000 & 0,05 & Valid \\
\hline \multirow{16}{*}{$\begin{array}{l}\text { Kinerja } \\
\text { (Y) }\end{array}$} & Y.1 & 0,696 & 0,3 & 0,000 & 0,05 & Valid \\
\hline & Y.2 & 0,433 & 0,3 & 0,000 & 0,05 & Valid \\
\hline & Y.3 & 0,706 & 0,3 & 0,000 & 0,05 & Valid \\
\hline & Y.4 & 0,649 & 0,3 & 0,000 & 0,05 & Valid \\
\hline & Y.5 & 0,738 & 0,3 & 0,000 & 0,05 & Valid \\
\hline & Y.6 & 0,656 & 0,3 & 0,000 & 0,05 & Valid \\
\hline & Y.7 & 0,540 & 0,3 & 0,000 & 0,05 & Valid \\
\hline & Y.8 & 0,576 & 0,3 & 0,000 & 0,05 & Valid \\
\hline & Y.9 & 0,421 & 0,3 & 0,000 & 0,05 & Valid \\
\hline & Y.10 & 0,827 & 0,3 & 0,000 & 0,05 & Valid \\
\hline & Y.11 & 0,685 & 0,3 & 0,000 & 0,05 & Valid \\
\hline & Y.12 & 0,637 & 0,3 & 0,000 & 0,05 & Valid \\
\hline & Y.13 & 0,482 & 0,3 & 0,000 & 0,05 & Valid \\
\hline & Y.14 & 0,648 & 0,3 & 0,000 & 0,05 & Valid \\
\hline & Y.15 & 0,777 & 0,3 & 0,000 & 0,05 & Valid \\
\hline & Y.16 & 0,775 & 0,3 & 0,000 & 0,05 & Valid \\
\hline
\end{tabular}

Berdasarkan tabel 2 diatas maka menunjukkan bahwa semua item pernyataan pada variabel independent dan dependent memiliki nilai $r>0,3$ dapat disimpulkan bahwa semua item pernyataan adalah valid. 


\section{b. Uji Reliabilitas}

Uji Reliabilitas dilakukan dengan tujuan untuk menguji sejauh mana alat pengukur dapat diandalkan atau dipercaya. Dalam Penelitian ini nilai reliabilitas suatu instrumen diterima jika memiliki Alpha Cronbach minimal 0,6 . Arikunto dalam Supriyanto dan Machfudz (2010:296), maka dapat disimpulan bahwa semua item pernyataan adalah reliabel (dapat diandalkan atau dipercaya).

Adapun hasil uji reliabilitas menggunakan program perhitungan spss versi 21.0 dapat dilihat pada tabel 3 dibawah ini:

Tabel 3 Rekapitulasi Hasil Uji Reliabilitas Instrumen Penelitian

\begin{tabular}{|c|c|c|c|}
\hline Variabel & $\begin{array}{c}\text { Item } \\
\text { Pernyataan }\end{array}$ & $\begin{array}{l}\text { Cronbach } \\
\text { Alpha }\end{array}$ & Keterangan \\
\hline $\begin{array}{l}\text { Budaya } \\
\text { Organisasi } \\
\text { (X1) }\end{array}$ & $\begin{array}{c}\mathrm{X} 1.1 \\
\mathrm{X} 1.2 \\
\mathrm{X} 1.3 \\
\mathrm{X} 1.4 \\
\mathrm{X} 1.5 \\
\mathrm{X} 1.6 \\
\mathrm{X} 1.7 \\
\mathrm{X} 1.8 \\
\mathrm{X} 1.9 \\
\mathrm{X} 1.10\end{array}$ & 0,957 & Reliabel \\
\hline $\begin{array}{l}\text { Motivasi } \\
\text { (X2) }\end{array}$ & $\begin{array}{c}\mathrm{X} 2.1 \\
\text { X2.2 } \\
\text { X2.3 } \\
\text { X2.4 } \\
\text { X2.5 } \\
\text { X2.6 } \\
\text { X2.7 } \\
\text { X2.8 } \\
\text { X2.9 } \\
\text { X2.10 } \\
\text { X2.11 } \\
\text { X2.12 } \\
\text { X2.13 } \\
\text { X2.14 } \\
\text { X2.15 }\end{array}$ & 0,970 & Reliabel \\
\hline $\begin{array}{l}\text { Kinerja } \\
(\mathrm{Y})\end{array}$ & $\begin{array}{c}\text { Y.1 } \\
\text { Y.2 } \\
\text { Y.3 } \\
\text { Y.4 } \\
\text { Y.5 } \\
\text { Y.6 } \\
\text { Y.7 } \\
\text { Y.8 } \\
\text { Y.9 } \\
\text { Y.10 } \\
\text { Y.11 } \\
\text { Y.12 } \\
\text { Y.13 } \\
\text { Y.14 } \\
\text { Y.15 }\end{array}$ & 0,901 & Reliabel \\
\hline
\end{tabular}

Berdasarkan tabel 3 diatas maka menunjukkan semua item pernyataan memiliki nilai Alpha Cronbach > 0,6 maka dapat disimpulan bahwa semua item pernyataan dalam penelitian ini adalah reliabel (dapat diandalkan atau dipercaya).

\section{Analisis Regresi Berganda}

Sebagaimana telah dirumuskan sebelumya bahwa hipotesis ini bahwa variabel Budaya Organisasi dan Motivasi Kerja berpengaruh signifikan secara simultan maupun parsial terhadap Kinerja Pegawai Dinas Ketahanan Pangan, Pertanian dan Perikanan Kabupaten Barito Selatan dan Budaya Organisasi merupakan variabel yang berpengaruh dominan terhadap kinerja pegawai Dinas Ketahanan Pangan, Pertanian dan Perikanan Kabupaten Barito Selatan.

Pengujian dilakukan dengan tingkat kepercayaan $95 \%$ atau tingkat signifikansi $0,05(\mathrm{a}=0,05)$, Untuk mengkaji kebenaran hipotesis - hipotesis tersebut digunakan analisis regresi linier. Pada analisis regresi ini akan dilakukan uji serentak atau uji $\mathrm{F}$ serta parsial atau uji $\mathrm{t}$ dengan nilai $\mathrm{t}$ tabel $=\mathrm{df}=\mathrm{n}-\mathrm{k}-1=78-3-1=74=1,993$ dan $\mathrm{F}$ tabel $=\mathrm{df} 1=\mathrm{k}-1=3-1=2$ df $2=\mathrm{n}-\mathrm{k}=78$ $3=75=3,120$, adapun rekapitulasi analisis regresi linier berganda dalam penelitian ini dapat dilihat pada tabel 4.11 dibawah ini :

\section{Tabel 4 Hasil Uji Regresi Linier Berganda}

\begin{tabular}{|l|c|c|c|c|c|}
\hline \multicolumn{1}{|c|}{ Variabel } & $\begin{array}{c}\text { Koefisien } \\
\text { Regresi } \\
\text { (bi) }\end{array}$ & t hitung & t tabel & beta & Sig \\
\hline Konstanta & 10,424 & \multicolumn{4}{l}{} \\
\hline Budaya Organisasi (X1) & 0,319 & 3,888 & 1,993 & 0,315 & 0,000 \\
\hline Motivasi (X2) & 0,677 & 7,557 & 1,993 & 0,612 & 0,000 \\
\hline Konstanta $=10,424$ & & F hitung $=95,504$ & & \\
\hline \\
Multiple $\mathrm{R}=0,853$
\end{tabular}


Pada tabel 4 dapat dilihat $\mathrm{R}$ Square sebesar 0,726 yang berarti besarnya variasi sumbangan seluruh variabel bebas terhadap variabel terikatnya adalah $72,6 \%$ sedangkan sisanya $27,4 \%$ dijelaskan oleh sebab lain diluar dari penelitian ini, berdasarkan hasil R2 yang diperoleh dalam penelitian ini mendekati 1 (satu) maka dapat dikatakan hubungan variabel bebas terhadap variabel terikat adalah kuat. Jika R2 yang diperoleh mendekati 1 (satu) maka dapat dikatakan semakin kuat model tersebut menerangkan hubungan variabel bebas terhadap variabel terikat. Sebaliknya jika R2 makin mendekati 0 (nol) maka semakin lemah pengaruh variabel-variabel bebas terhadap variabel terikat

Berdasarkan tabel 4 diperoleh persamaan regresi sebagai berikut:

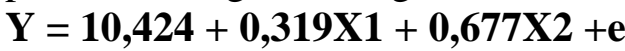

\section{Pembahasan}

Berdasarkan hasil penelitian pada hasil penelitian diatas dapat dilihat Budaya Organisasi dan Motivasi berpengaruh signifikan secara simultan terhadap Kinerja Pegawai Dinas Ketahanan Pangan, Pertanian dan Perikanan Kabupaten Barito Selatan, hal ini dapat dilihat dari hasil perhitungan statistik dengan menggunakan program bantuan perhitungan statistik versi 21.0

Dengan demikian hipotesis pertama yang mengatakan Budaya Organisasi dan Motivasi berpengaruh secara simultan Terhadap Kinerja Pegawai Dinas Ketahanan Pangan, Pertanian dan Perikanan Kabupaten Barito Selatan adalah teruji atau terbukti benar.

Berdasarkan hasil penelitian dapat dilihat Budaya Organisasi dan Motivasi berpengaruh secara parsial Terhadap Kinerja Pegawai Dinas Ketahanan Pangan, Pertanian dan Perikanan Kabupaten Barito Selatan, hal ini dapat dilihat dari hasil perhitungan statistik dengan menggunakan program bantuan perhitungan statistik versi
21.0 variabel Budaya Organisasi berpengaruh signifikan terhadap Kinerja Pegawai Dinas Ketahanan Pangan, Pertanian dan Perikanan Kabupaten Barito Selatan. Budaya Organisasi harus diciptakan dengan baik di organisasi yaitu dengan bersama-sama berkomitmen terhadap organisasi untuk mencapai tujuan organisasi, visi dan misi serta bekerja sesuai dengan harapan organisasi, karena kerjasama tim kerja merupakan suatu hal utama yang mendukung kesuksesan dalam bekerja budaya organisasi yang seperti itu harus ada dan terus diciptakan di organisasi selain itu organisasi juga memberikan kelengkapan fasilitas teknologi informasi, komputer yang memadai, internet, serta fasilitas pendukung lainnya yang memadai guna menunjang pekerjaan pegawai.

Berdasarkan hasil jawaban responden atas kuesioner pertanyaan variabel Budaya Organisasi dominan menjawab sangat setuju bahwa mereka dihargai dalam memberikan ide untuk memajukan dan mengembangkan organisasi, dapat memberikan toleransi kepada pegawai lainnya untuk dapat bertindak agresif dan inovatif, berani mengambil resiko terhadap apa yang dikerjakan selama ini, bekerja sesuai sasaran yang jelas tercantum dalam visi, misi, dan tujuan organisasi, kondisi pekerjaan yang di hadapi selama ini dapat berpengaruh terhadap kinerja organisasi, pegawai selalu bekerja dengan kompak dan terkoordinir di kantor, pegawai selalu bekerja dengan kompak dan terkoordinir antar unit - unit organisasi lain dalam mendorong kualitas dan kuantitas kerja yang baik, seluruh pegawai di berikan identitas tanda pengenal sebagai pegawai, Identitas sepeti papan nama pada meja kerja diberikan kepada semua pegawai dan Kewenangan pimpinan dapat menghambat terjadinya pola komunikasi pada organisasi. Variabel Motivasi berpengaruh signifikan terhadap Kinerja Pegawai Dinas 
Ketahanan Pangan, Pertanian dan Perikanan Kabupaten Barito Selatan. Motivasi kedepannya harus diperhatikan oleh organisasi kepada pegawai seperti pemberian bonus, honor atas pencapaian kinerja yang telah di capai pegawai, kesempatan untuk pengembangan karir yaitu promosi dalam jabatan serta memberikan penghargaan berupa pujian dari atasan kepada pegawai yang telah bekerja dengan baik.

Berdasarkan hasil jawaban responden atas kuesioner pertanyaan variabel Budaya Organisasi dominan menjawab sangat setuju apabila kantor tempat bekerja memberikan kebijaksanaan yang baik, sistem administrasinya sudah tertata dengan baik, dan selalu dikembangkan dengan teknologi dan informasi, Pimpinan selalu melakukan supervisi, Supervisi dilakukan dengan tujuan memonitor pekerjaan bawahan, dan untuk memastikan koordinasi pekerjaan antar bidang berjalan baik. Selain gaji, pegawai diberikan tambahan penghasilan lainnya, yang diberikan tepat waktu, hubungan antara pimpinan dengan bawahan maupun sesame pegawai terjalin harmonis. Keberhasilan pegawai akan dijadikan ukuran prestasi, Dinas Ketahanan Pangan, Pertanian dan Perikanan Kabupaten Barito Selatan memberikan penghargaan kepada pegawai yang memiliki prestasi contohnya tambahan nilai pada sasaran kerja pegawai (SKP) pegawai serta direkomendasikannya pegawai dalam pengembangan karir pegawai, pegawai termotivasi pekerjaan karena menyukai pekerjaannya dan Pekerjaan yang diberikan kepada pegawai sudah dianalisa sesuai keahlian pegawai.

Berdasarkan tabel 4.11 hasil penelitian dapat dilihat variabel Motivasi merupakan variabel yang dominan berpengaruh terhadap Kinerja Pegawai Dinas Ketahanan Pangan, Pertanian dan Perikanan Kabupaten Barito Selatan. Pegawai akan menunjukan kinerja yang baik karena faktor pemberian motivasi yang baik dari Dinas Ketahanan Pangan, Pertanian dan Perikanan Kabupaten Barito Selatan, pemberian motivasi yang selalu tepat waktu serta perhatian pemberian dukungan motivasi kepada pegawai untuk bekerja dengan baik dan memberikan pengakuan penghargaan sekecil apapun prestasi yang telah di hasilkan pegawai.

\section{Kesimpulan}

Berdasarkan hasil analisis dan pembahasan yang telah diuraikan pada bab-bab sebelumnya, maka kesimpulan penelitian ini adalah:

1. Budaya Organisasi dan Motivasi berpengaruh signifikan secara simultan terhadap Kinerja Pegawai Dinas Ketahanan Pangan Pertanian Dan Perikanan Kabupaten Barito Selatan .

2. Budaya Organisasi dan Motivasi berpengaruh signifikan secara parsial terhadap Kinerja Pegawai Dinas Ketahanan Pangan Pertanian Dan Perikanan Kabupaten Barito Selatan .

3. Variabel yang berpengaruh dominan terhadap Kinerja Pegawai Dinas Ketahanan Pangan Pertanian Dan Perikanan Kabupaten Barito Selatan adalah Motivasi.

\section{Daftar Pustaka}

Amstrong .2012. Manajemen Sumber Daya Manusia. Alih Bahasa. Sofyan. Cikmat dan Haryono. Elex Media Komputindo. Jakarta.

Arikunto, Suharsimi. 2012. Prosedur Penelitian Suatu Pendekatan Praktik. Rineka Cipta .Jakarta .

Dharma, Surya .2012. Manajemen Kinerja. Edisi ketiga. Pustaka Pelajar: Yogyakarta.

Ghozali, Imam. 2012. Aplikasi Analisis Multivariate dengan program SPSS, Badan. Penerbit Universitas Diponegoro, Semarang.

Gibson .2012. Perilaku organisasi”. Rineka

Cipta. Jakarta. 
Gomes . Faustino Cardoso, 2012, Manajemen Sumber Daya Manusia, Penerbit Andi,. Yogyakarta.

Hasibuan, H. Malayu S.P. .2012. Manajemen: Dasar, Pengertian, dan Masalah", Edisi Revisi. Bumi Aksara. Jakarta.

Hastono, S.P. 2012. Analisis Data. Universitas Indonesia. Jakarta.

Hofstede .2012. Cultures and Organizations: Software of the Mind. New. York: McGraw-Hill USA.

Jamaluddin, Rudi Salam, Harisman Yunus dan Haedar Akib. 2017. Pengaruh Budaya Organisasi terhadap Kinerja Pegawai pada Dinas Pendidikan Provinsi Sulawesi Selatan. Jurnal Pemikiran Ilmiah dan Pendidikan Administrasi Perkantoran, Vol. 4, No. 1, 2017. https://ojs.unm.ac.id. Diakses 28 Agustus 2019.

Mangkunegara .2012. Evaluasi Kinerja Sumber Daya Manusia. Refika Aditama. Jakarta.

Rivai, Veithzal .2012. Manajemen Sumber Daya Manusia untuk Perusahaan dari. Teori kePraktik. PT Raja Grafindo Persada. Jakarta .

Robbins .2012. Prinsip-prinsip Perlaku Organisasi. Edisi kelima , Penerbit. Erlangga, Jakarta.

Sedarmayanti. 2012. Manajemen Sumber Daya Manusia. Ilham Jaya. Bandung.

Sekaran, Uma 2012, Research Methods For Business, Edisi 4, Buku 1, Salemba Empat. Jakarta.

Siagian, Sondang .2012. Manajemen Stratejik, Edisi keenam, PT. Bumi Aksara, Jakarta.

Soetjipto .2012. Budaya Organisasi. Gramedia. Jakarta.
Sritua, Arief .2012. Metodologi Penelitian Ekonomi. Universitas. Indonesia. Jakarta.

Sugiyono,Dr .2012. Metode Penelitian Kuantitatif Kualitatif dan $R \& D$. Alfabeta. Bandung.

Sunyoto, Danang .2012. Manajemen Sumber Daya Manusia. CAPS. Yogyakarta.

Supomo, B., 2012, Metodologi Penelitian Bisnis, BPFE-Yogyakarta. Yogyakarta.

Susanto .2013. "Leadpreneurship", Erlangga. Jakarta.

Syafitri Diah Kusumawati. 2014. Pengaruh Budaya Organisasi Dan Motivasi Kerja Terhadap Kinerja Pegawai Di Kantor Regional I Badan Kepegawaian Negara Yogyakarta. https://eprints.uny.ac.id. Diakses 28 Agustus 2019.

Umar, Husein. 2012. Metode Penelitian Untuk Skripsi dan Tesis Bisnis", Raja Grafindo Persada. Jakarta.

Yulpa Rabeta. 2018. Pengaruh Budaya Organisasi dan Motivasi terhadap Kinerja Pegawai di Dinas Pekerjaan Umum dan Penataan Ruang Kota Lubuklinggau. USU. Medan. 